Конструкція і теорія сільськогосподарських машин Construction and theory of agricultural machines

УДК 001.32

https://doi.org/10.37700/enm.2020.3(17).58 - 64

\title{
Розвиток наукових ідей Академіка П.М. Василенка діяльності кафедри що носить його ім'я
}

\author{
Д.Г. Войтюк ${ }^{1}$, Л.В. Аніскевич ${ }^{2}$, Ю.О. Гуменюк ${ }^{3}$, І.М. Сівак ${ }^{4}$ \\ Національний університет біоресурсів і природокористування України \\ (м.Київ, Україна) ORCID ${ }^{1}$ 0000-0001-6163-6334; ${ }^{2}$ 0000-0002-8595-3972; \\ ${ }^{3}$ 0000-0003-2463-1950; ${ }^{4}$ 0000-0002-6297-587X
}

\begin{abstract}
Стаття присвячується 120-й річниці від дня народження Петра Мефодійовича Василенка - видатного вченого в галузі агроінженерної науки, корифея землеробської механіки, академіка ВАСГНІЛ, академіка НААНУ, академіка РАСГН, члена-кореспондента НАНУ, доктора технічних наук, професора, лауреата найвищої нагороди у галузі механізації та електрифікації сільського господарства - Золотої медалі імені академіка В.П. Горячкіна. Дане дослідження висвітлює внесок академіка П.М. Василенка у формування та розвиток наукової дисципліни «Землеробська механіка», як технічної науки, що розвивається у тісному зв'язку із потребами сільськогосподарського виробництва і вивчає механіку сільськогосподарських середовищ і матеріалів, технологічних процесів і операцій, машин і механізмів, машинних агрегатів, поточних ліній і систем машин, динаміку системи людинамашина у сільському господарстві, а також технологічні процеси, засновані на використанні немеханічних (теплових, електричних і інших) видів енергії, і розробляє методи інженерного розрахунку і проектування для механізації і автоматизації сільського господарства". Близько 70 років плідної науково-педагогічної діяльності академіка П.М. Василенка пов'язано з кафедрою сільськогосподарських машин. Розглянуто основні напрямки діяльності наукової школи академіка П.М. Василенка та сучасні напрямки розвитку нових технологічних систем і техніки, над реалізацією яких успішно працюють науковці кафедри, що носить ім'я академіка П.М. Василенка В статті також наведені основні результати науково-технічної та інноваційної діяльності, кафедри сільськогосподарських машин та системотехніки ім. акад. П.М. Василенка за останні роки її функціонування.
\end{abstract}

Ключові слова: наука; техніка; дослідження; інновації; кафредра.

17 жовтня 2020 року є знаковою подією для багаточисельної студентської молоді, вчених, педагогів, конструкторів, інженерів в галузі механізації і автоматизації сільського господарства. В цей день виповнюється 120 років від дня народження Петра Мефодійович Василенка - видатного вченого зі світовим ім'ям в галузі агроінженерної науки, корифея землеробської механіки, академіка ВАСГНІЛ, академіка НААН У, академіка РАСГН, члена-кореспондента НАНУ, доктора технічних наук, професора, лауреата найвищої нагороди у галузі механізації та електрифрікації сільського господарства - Золотої медалі імені академіка В.П. Горячкіна.

Близько 70 років його плідної науково-педагогічної діяльності пов'язано з кафедрою сільськогосподарських машин, заснованою в 1898 році на сільськогосподарському відділенні Київського політехнічного інституту професором К.Г. Шінд- лером. У свій час на кафредрі працювали видатні вчені: професори Л.П. Крамаренко, П.Я. Вовк, академіки: А.О. Василенко, О.М. Карпенко.

Найбільші наукові здобутки кафедри розпочинається з призначенням восени 1935 року на посаду завідувача П.М. Василенка. Завдяки своїм видатним науковим здібностям вирішувати найважливіший задачі землеробський механіки з використанням аналітичної механіки, він по праву визнається правонаступником і послідовником вчення академіка В.П. Горячкіна.

За його безпосередньої участі в 1976 році на Всесоюзній науковій конфреренції з проблем землеробської механіки присвяченій пам'яті академіка В.П. Горячкіна було сорормовано визначення наукової дисципліни землеробська механіка: - це "технічна наука, що розвивається у тісному зв'язку із потребами сільськогосподарського виробництва і вивчає механіку сільськогосподарських 
середовищ і матеріалів, технологічних процесів і операцій, машин і механізмів, машинних агрегатів, поточних ліній і систем машин, динаміку системи людина-машина у сільському господарстві, а також технологічні процеси, засновані на використанні немеханічних (теплових, електричних і інших) видів енергії, і розробляє методи інженерного розрахунку і проектування для механізації і автоматизації сільського господарства".

В розвиток цієї науки академік П.М. Василенко вніс неоціненний вклад, опублікувавши більше 200 наукових праць, серед яких 12 підручників і фундаментальних монографій, остання 3 яких "Введение в земледельческую механику" вийшла з друку у 1996 році, коли йому виповнилося 96 років. Широкий спектр його наукових розробок стосується трьох основних напрямків:

- класичні основи землеробства і механіки, як однієї з галузей прикладної механіки;

фундаментальні теоретичні механікоматематичні дослідження, спрямовані на розвиток нових методів розв'язання задач аналізу і синтезу параметрів сільськогосподарських машин та машинних агрегатів, які досліджуються і проектуються;

- прикладні технічні розробки конструктивних елементів для створення принципово нових та модернізації існуючих зразків сільськогосподарських машин;

Розробки першого напрямку стосуються застосування загальних фундаментальних принципів аналітичної механіки для розв'язання задач механіки сільськогосподарського середовища, руху матеріальної точки і матеріальної частинки, системи матеріальних точок та твердого тіла.

Другий напрямок стосується розвитку сучасних сільськогосподарських машин, як більш складних та багатовимірних систем порівняно з простими сільськогосподарськими знаряддями та машинами, потребує більш фундаментальних механіко-математичний методів, зокрема аналітичної механіки, що базується на реальних рівняннях динаміки Лагранжа, Гамільтона-Остроградського, Апеля, Чаплигіна, тощо. Академік П.М. Василенко першим у світі почав розробляти методику складання та розв'язання складних систем диференціальних рівнянь для розрахунку параметрів сільськогосподарської техніки (машин і агрегатів) які проектуються. Він науково обґрунтував та математично довів, що методи аналізу та синтезу, які широко використовувались раніше на підставі праці академіка Горячкіна В.П. та його учнів для дослідження і проектування маломірних механічних систем і нескладних сільськогосподарських машин уже недостатні, якщо системи $є$ багатомірними то їхні конфігурації належить не тільки до залежних, але й до незалежних координат. Коректне розв'язання задач з такими пара- метрами потребує складання і вирішення рівнянь в'язів і застосування більш складних рівнянь Лагранжа II роду з неозначеними множниками і подальшого використання усіх необхідних процедур для їх вирішення.

Третій напрям розробок вченого здійснювався шляхом тісного співробітництва з СКБ та ГСКБ заводів сільськогосподарського машинобудування, яке надавало можливість втілити вищезазначені теоретичні методи проектування нових сільськогосподарських машин та їхніх робочих органів.

Багато фундаментальних наукових праць академіка П.М. Василенка без перебільшення можна віднести до світової наукової скарбниці [1, 2, 3, 4, 5].

Важливої уваги заслуговує видатна наукова школа створена академіком П.М. Василенком: під його безпосереднім керівництвом захищено близько 60 кандидатський і 10 докторських дисертаційних робіт, декілька його учнів стали докторами наук уже після його смерті. Багато учнів академіка П.М. Василенка вже самі досягли значних наукових успіхів - працювали і працюють у науково-дослідних лабораторіях та конструкторських бюро, очолюють кафедри, факультети і провідні науково-дослідні інститути, обрані членамикореспондентами та дійсними членами академій наук, створили свої наукові школи(академіки: Л.В. Погорілий, В.М. Булгаков).

Ім'я академіка Петра Мефодійовича Василенка стоїть поряд з іменами багатьох видатних вчених у книзі "700 біографій найвидатніших людей планети XX століття", виданій Американським Біографічний Інститутом (АБІ).

Не доживши майже півтора року до свого 100-річчя, П.М. Василенко помер 21 квітня 1999 року, залишивши після себе неоціненний науковий скарб.

Для вшанування пам'яті академіка П.М. Василенка був виданий наказ по університету, витяг 3 якого наведено нижче (рис. 1.).

Започаткована у 2000 році з нагоди 100-річчя від дня народження академіка П.М. Василенка міжнародна наукова конференція актуальних проблеми землеробської механіки проводиться щорічно в день його народження в різних містах України, де фрунціонують аграрні ВУЗи з інженерними фракультетами або науково-дослідні установи агроінженерного профілю.

На пошану академіка видані книги $[6,7,8]$, у яких відображено його складне багатогранне життя впродовж буремного XX століття, плідна творча праця і видатні наукові здобутки, які слугують для всіх, хто мав щастя близько його знати, невичерпним джерелом творчості та натхнення, відданості справі науки.

Справа видатного вченого, академіка продовжується в численних наукових працях його учнів 
та послідовників, які здобувають нові знання в дослідженні проблем землеробської механіки.

Тут доречно нагадати думку організатора академічної науки в Україні академіка В.І. Вернадського: "Історія науки і її минуле повинно критично складатися кожним науковим поколінням і не тільки тому, що змінюються закони таких знань про минуле, відкриваються нові документи або знаходяться нові заходи з відновлення того, що було. Нi! Необхідно знову науково перепра- цювати історію науки, знову історичну повернутися до минулого, бо завдяки розвитку сучасного знання в минулому отримує $є$ значення одне i втрачає інше..."[9].

Дбаючи про подальший розвиток науки із землеробської механіки та сприяючи розвитку нових технологічних систем і техніки, науковці кафедри, що носить ім'я академіка П.М. Василенка успішно працюють над реалізацією наукових ідей свого вчителя.

\section{ВИТЯГ З НАКАЗУ}

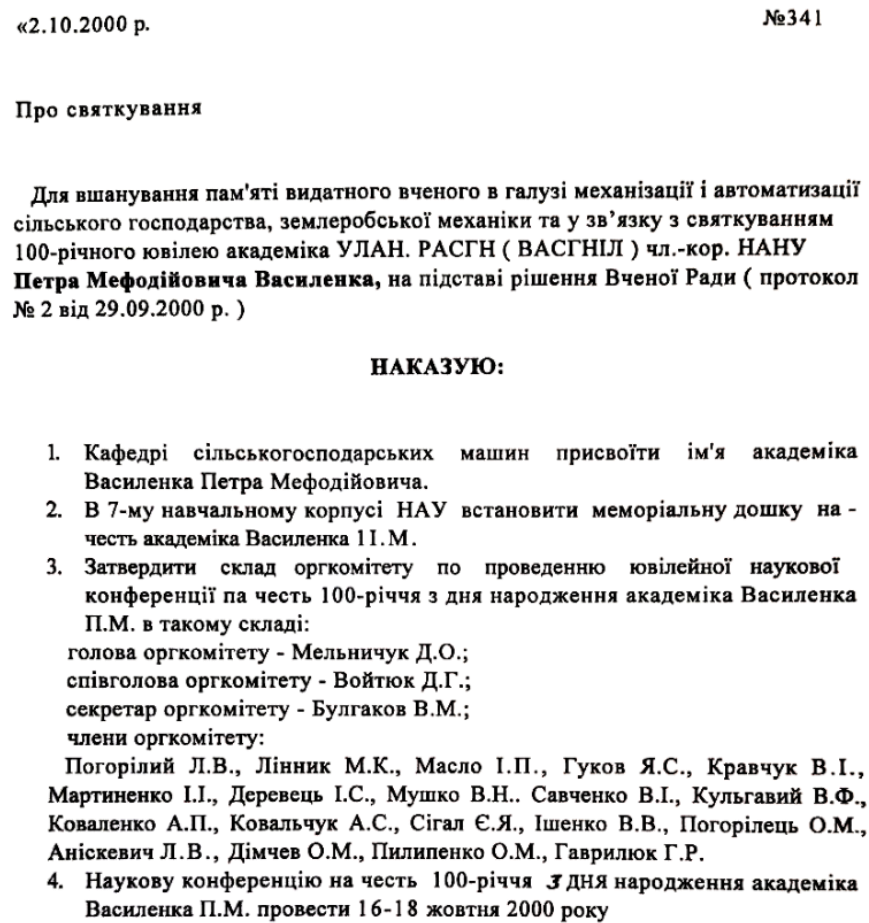

НАКАЗУЮ:

1. Кафедрі сільськогосподарських машин присвоїти ім'я академіка Василенка Петра Мефодійовича.

2. В 7-му навчальному корпусі НАУ встановити меморіальну дошку на честь академіка Василенка 1І.М.

3. Затвердити склад оргкомітету по проведенню ювілейної наукової конференції па честь 100-річчя 3 дня народження академіка Василенка П.М. в такому складі:

голова оргкомітету - Мельничук Д.О.;

співголова оргкомітету - Войтюк Д.Г.;

секретар оргкомітету - Булгаков В.М.;

члени оргкомітету:

Погорілий Л.В., Лінник М.К., Масло І.П., Гуков Я.С., Кравчук В.І., Мартиненко I.I., Деревець І.С., Мушко В.Н.. Савченко В.І., Кульгавий В.Ф. Коваленко А.П., Ковальчук А.С., Сігал Є.Я., Ішенко В.В., Погорілець О.М., Аніскевич Л.В., Дімчев О.М., Пилипенко О.М., Гаврилюк Г.Р.

4. Наукову конференцію на честь 100-річчя 3 дНя народження академіка Василенка П.М. провести 16-18 жовтня 2000 року

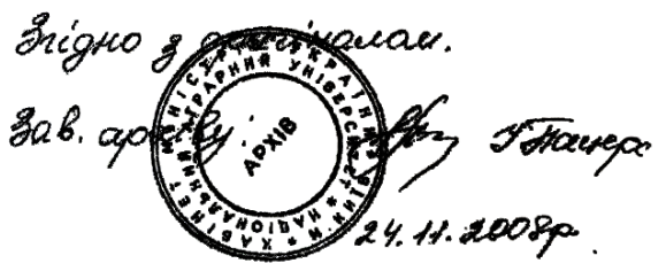

Рис.1. Витяг з наказу про вшанування пам'яті академіка П.М. Василенка та присвоєння кафредрі сільськогосподарських машин його імені.

Актуальні проблеми оптимізації впливу ходових систем машинних агрегатів на ущільнення ґрунту під час вирощування сільськогосподарських культур вирішували співробітниками кафедри
В.С. Гапоненком, П.С. Короткевичем, О.В. Ямковим, О.М. Дімчевим.

У 1997 році вперше в Україні започатковано новий науковий напрямок розробки механіко- 
технологічний основ системи точного землеробства (СТ3), схвально сприйнятий академіком П.М. Василенком. У формуванні ідейного та теоретичного рівня Проблемної лабораторії приймали участь: Л.В Аніскевич., Д.Г. Войтюк, М.С. Волянський, С.В. Смолінський, О.В. Ямков, О.О. Броварець, О.М. Вечера, Ю.О. Росамаха.

Дослідження ПЛТЗ зосереджувалися на обґрунтуванні науково-практичних основ застосування безпілотних польових інформаційних машин в рослинництві з розробкою теорії побудови навігаційно-управляючого комплексу машин та методики обробітку комплексної навігаційної інфрормації. Вперше у світовій практиці (патент України на винахід № 69902, 2012 року) запропонована нова методика отримання високоточної інформації про місцевизначену врожайність для побудови картограм урожайності із використанням інтегральної моделі Дюамеля, на основі імпульсних перехідних характеристик збиральних машин в функції часу:

$$
\lambda_{3}(t)=\int_{0}^{1} \delta(t-T) \lambda_{ж}(T) d t 1,
$$

де $\lambda_{3}(t)$ - покази датчика маси зерна, $\delta(t-T)$ імпульсна перехідна функція динамічної системи комбайна, $\lambda_{\text {ж }}$ - інтенсивність вхідного потоку зернової частини хлібної маси на різальному апараті жатки.

Методика включає комбінацію спеціально розроблених алгоритмів відновлення інтенсивності вхідного потоку зерна за даними датчика маси зерна комбайна. На початковій і кінцевій ділянках картографування врожайності (на вході та на виході кожного гону комбайна), а також на ділянках з різкою зміною інтенсивності потоку зерна в бункер використовується комбінація так званого "стрічкового" алгоритму та алгоритму екстраполяції за швидкістю з ваговими коефіцієнтами, що налагоджуються. На інших ділянках роботи комбайна використовується запропонований диференціальний алгоритм.

Для вирішення проблем нерівномірного завантаження робочих органів комбайна технологічними матеріалами внаслідок зміни рівня місцевизначеної врожайності та умов комбайнування по напрямку ходу машини на рівні світової новизни (патенти України: № 79450, № 79451, 2013 року) запропоновано методику прогностичного способу регулювання режимів функціонування робочих органів збиральної машини.

Щоб забезпечити підвищену точність і надійність виконання польових механізованих операцій за технологіями СТ3 (патент України на корисну модель №68193) розроблено методику обробітку комплексної навігаційної інформації з процедурою калмановської фрільтрації "розщепленого" типу, яка дозволяє визначити необхідний склад та техніко-технологічні вимоги до наві- гаційного обладнання. Заслуговують на увагу перспективні дослідження технологічного процесу місцевизначеної сівби, особливо просапних культур, для яких необхідно забезпечити таку заробки насіння, при якій будуть дотримані оптимальні значення тепла, вологи, поживних речовин, аерації, достатньої площі для росту і розвитку рослини. Довкола насінини необхідно сформувати ядро ущільненого і зволоженого ґрунту, а зверху утворити дрібногрудочкувату і ущільнену до 1,3 г/см3 структуру. Причому 90\% насінин повинні залягати на заданій (з допустимим відхиленням) глибині незалежно від стану нерівностей поверхні поля. Для досягнення описаних вимог запропоновану двофазний спосіб заробки насіння. На першій фазі конусний щілиноутворювач входить в Ґрунт і формує щілину зі сприятливими до заклинювання в ній насіння геометричними параметрами, в яку подається насіння. На другій фразі вступає в роботу вдавлюючий диск з певними геометричними параметрами, який переміщує насінину донизу з утворенням ущільненого шару довкола насіння (патент України на корисну модель №107387, 2016 року).

Ефективність технології точного землеробства пов'язана з пошуком новітніх способів внесення технологічних матеріалів. Традиційні способи внесення технологічних матеріалів здійснюється за допомогою машинно-тракторних агрегатів у контакті з сільськогосподарським полем розкидним способом, ефективність якого відносно низька. Запропоновано (патент України на корисну модель №100986, 2015 року) принципово новий балістичний спосіб внесення технологічних матеріалів. Такий спосіб внесення технологічних матеріалів у точному землеробстві дозволяє уникнути негативного впливу опорну ходових систем МТА на ґрунт, різко знижує витрати паливно-мастильних матеріалів, сприяє значному підвищенню точності і продуктивності реалізації технологій змінних норм внесення технологічних матеріалів, а також сприяє заощадженню останніх в середньому на $20-22 \%$.

Зважаючи на світові тенденції розвитку інформаційних технології в аграрній галузі, виникає необхідність теоретичного і практичного обґрунтування законів новітнього напряму формування та функціонування природних, антропо-природних та культурних екосистем та їх біогеоценозів на основі інформаційних технологій і екології та інформаційних технологій біогеоценології. Такі дослідження співробітників кафедри спільно з науковцями біологічного профрілю та навігаційних систем узагальненні монографії “Прецизійні фрітотехнології в агропромисловому комплексі України”, виданий в 2019 році в НУБіП України [10].

Важливі дослідження розпочаті на кафедрі по вивченню впливу електромагнітного випроміню- 
вання крайньовисокочастотного (КВЧ) діапазону на біологічні об'єкти, а також дослідження фрізичних механізмів, які лежать в основі резонансного поглинання та інформаційного впливу мікрохвиль на насіння і рослини [11].

Одним з актуальних та перспективних наукових напрямків досліджень $є$ техніко-технологічне забезпечення виробництва органічної продукції. Для забезпечення замкнутого циклу вирощування екологічно чистої рослинної продукції, поряд зі створенням машин для внесення пестицидів, на кафедрі започатковано лабораторію "Техніко-технологічного забезпечення виробництва і застосування мікобіопрепаратів".

Крім розглянутих вище інноваційних досліджень в галузі землеробської механіки на кафедрі належна увага приділяється дослідженню і удосконаленню традиційних машин і їх робочих органів. Так важливими є дослідження динаміки руху ґрунтообробних машин, зокрема питання адаптації робочих органів до ґрунтових умов, а також дослідження з вивчення впливу ґрунтообробних операцій на процес емісії вуглекислого газу $\left(\mathrm{CO}_{2}\right)$, і пошук умов його секвестрації в ґрунті, що сприяє вирішенню проблем парникового ефекту.

У зв'язку з відсутністю власного комбайнобудування в Україні співробітниками кафедри у 2010 році виступили з ініціативою створення спільного виробництва 3 фрінською компанією «Sampo-Rosenlew» зернозбирального комбайна на заводі «Точмаш» у м. Переяслав-Хмельницький. Була створена адаптована до українських умов, з допустимим рівнем локалізації, модель зернозбирального самохідного комбайна «Сампо-Україна 300», який у 2012 році пройшов державні приймальні випробування і був рекомендований до виробництва.

Проведені дослідження у напрямі удосконалення бурякозбиральної техніки шляхом обґрунтування параметрів та режимів роботи гичкозбиральних і викопуючих робочих органів з метою зменшення енергоємності їх робочих процесів. Досліджено схему компоновки бурякозбирального агрегата і досягнуто підвищення технологічності копіювання напряму рядків коренеплодів, що значно зменшує втрати останніх при збиранні.

Визначено і обґрунтовано конструктивні параметри, розраховано технологічні режими, енергетичні і тягово-зчіпний властивості надлегкого мобільного енергетичного засобу, досліджено динаміку його руху, обґрунтовано конструктивні параметри технологічних модулів до нього із застосуванням методів статистичної динаміки.

Широкий спектр досліджень виконано по обґрунтуванню параметрів і режимів роботи машин для захисту рослин. Розроблено обприскувач польових культур із регульованою дисперсією крапель та пневматичною системою осадження крапель робочих рідин, а також обприскувач польових культур з автоматичним регулюванням норми внесення, які пройшли державні приймальні випробування в УкрНДІПВТ ім. Л. Погорілого. Обприскувачі дозволяють забезпечити внесення змінної норми робочої рідини шляхом автоматичного підбору розпилюючих насадок для здійснення заданої якості виконання технологічного процесу за різних технологічних умов. Розроблено і виготовлено нові стаціонарні універсальні протруювачі безперервної дії інерційно-фрикційного типу ПНУ-4 і ПНУ-10 у співпраці з науковцями ННЦ “ІМЕСГ” НААН України.

Протруювачі здійснюють дозування, розподілення насіння і обробкою його нерозпиленим рідким препаратом за допомогою одного робочого органу. В машинах реалізується процес нанесення рідких препаратів на насіння сільськогосподарських культур за рахунок інерційних сил і використання бокової поверхні зернівки як робочої. В результаті порівняльної оцінки основних технічних, технологічних і експлуатаційних показників протруювачі в різних типів встановлено незаперечну перевагу розроблених протруювачі в інерційно-фррикційного типу.

На кафредрі багато уваги приділяється дослідженню історії розвитку сільськогосподарської техніки, сільськогосподарського машинобудування, фрілософії техніки, як науки та наукової спадщини українських діячів науки і техніки. Розвиваючи наукові ідеї академіка ПМ Василенка співробітниками кафедри за останні років захищену 3 докторські, 8 кандидатських дисертацій, опубліковано 2 фундаментальні монографії [10, 11], видано 8 підручників [12-19] і 5 навчальних посібників [20-24].

\section{Література:}

1. Культиватори: конструкція, теория и расчет. П.М. Василенко, П.Т. Бабий . - К.: Изд-во УАСХН, 1961. - 239 c.

2. Автоматизация процессов сельскохозяйственного производства/П.М. Василенко, И.И. Василенко. - М.: Колос, 1964. - 384 с.

3. Теория движения частицы по шероховатым поверхностям сельскохозяйственных машин/ П.М. Василенко. - К.: УСХА, 1960. - 283 с.

4. Автоматизация процессов сельскохозяйственного производства/ П.М. Василенко, И.И. Василенко. - М.: Колос, 1972. - 576 с.

5. Введение в земледельческую механику /П.М. Василенко. - К.: Сільгоспосвіта, 1996. - 252 с.

6. Василенко Петро Мефодійович. Бібліографрічний показник наукових праць з 1933 - 1999 роки. - К.: Аграрна освіта, 2000. - 128 с.

7. Академік П.М. Василенко, яскравий погляд у майбутнє. - К.: Хай-Тек Прес, 2010. - 510 с.

8. Академік П.М. Василенко - корифей землеробської механіки в Україні. За ред. С.М. Ніколаєнка. - К.: Аграрна наука, 2015. - 264 с.

9. Вернадський В.И. Труды по истории науки. М.: Наука, 2002. - С. 193. 
10. Прецизійні фрітотехнології в агропромисловому комплексі України: Монографрія. К.: НУБіП України, 2017. - 798 с.

11. Механізми взаємодії крайвисокочастотного випромінювання з біологічними об'єктами та їх моделювання: Монографрія. К.: НУБіП України, 2017. $-626 \mathrm{c}$.

12. Механіко-технологічні властивості сільськогосподарських матеріалів: Підручник. За ред. С.С. Яцуна. - К.: Мета, 2003. - 448 с.

13. Сільськогосподарські та меліоративні машини: Підручник. За ред. Д.Г. Войтюка. - К.: Вища освіта, 2004. - 544 с.

14. Сільськогосподарські машини: Підручник. За ред. Д.Г. Войтюка. - К.: Каравела, 2004. - 552 с.

15. Сільськогосподарські машини. Основи теорії та розрахунку: Підручник. За ред. Д.Г. Войтюка. - К.: Вища освіта, 2005. - 464 с.

16. Механізація, електрифікація та автоматизація сільськогосподарського виробництва: Підручник у 2 томах. За ред. А.В. Рудя. - К.: Агроосвіта, 2012, Т. I - 584 с, Т. II - 432 с.

17. Сільськогосподарські машини: Підручник. За ред. Д.Г. Войтюка. - К.: Агроосвіта, 2015. -679 с.

18. Сільськогосподарські машини. Основи теорії та розрахунку: Підручник. За ред. Д.Г. Войтюка, 2-е видання, перероб. та доп. - К.: НУБіП України, 2018. - 736 с.

19. Система точного землеробства: Підручник. За ред. Л.В. Аніскевича. - К.: НУБіП України, 2018. - $566 \mathrm{c}$.

20. Сільськогосподарські машини. Основи теорії та розрахунку: Навчальний посібник. За ред. Д.Г. Войтюка. - Суми: ВТД «Університетська книга», 2008. - 543 с.

21. Теорія сільськогосподарських машин. Практикум: Навч. посібник/ За ред. С.С. Яцуна. Суми: ВТД «Університетська книга», 2008. -201с.

22. Інформаційні системи і технології: Навчальний посібник. - Ніжин: Видавець ПП Лисенко M.M., 2014. -616 c.

23. Сільськогосподарські машини. Навчальний посібник. - К.: Агроосвіта, 2017. - 180 с.

24. Машини для рослинництва. Практикум. Ніжин: Видавець ПП Лисенко М.М., 2017. - 352 с/

\section{References}

1. Vasylenko P.M., Babyi P.T. Kultyvatorb: konstruktsyia, teoryia y raschet. - K.: Yzd-vo UASKhN, 1961. - $239 \mathrm{p}$.

2. Vasylenko P.M., Vasylenko Y.Y. Avtomatyzatsyia protsessov selskokhoziaistvennoho proyzvodstva/ Vasylenko P.M., Vasylenko Y.Y. - M.: Kolos, 1964. $-384 \mathrm{p}$.

3. Vasylenko P.M. Teoryia dvyzhenyia chastytsы po sherokhovatum poverkhnostiam selskokhoziaistvennыkh mashyn / Vasylenko P.M. K.: USKhA, 1960. - 283 p.

4. Vasylenko P.M., Vasylenko Y.Y. Avtomatyzatsyia protsessov selskokhoziaistvennoho proyzvodstva / Vasylenko P.M., Vasylenko Y.Y. - M.: Kolos, 1972. $-576 \mathrm{p}$.
5. Vvedenye $v$ zemledelcheskuiu mekhanyku / Vasylenko P.M. K.: Silhosposvita, 1996. - 252 p.

6. Vasylenko Petro Mefodiiovych. Bibliohrafichnyi pokaznyk naukovykh prats z 1933 - 1999 roky. - K.: Ahrarna osvita, 2000. - 128 p.

7. Akademik P.M. Vasylenko, yaskravyi pohliad u maibutnie. - K.: Khai-Tek Pres, 2010. -510 p.

8. Akademik P.M. Vasylenko - koryfei zemlerobskoi mekhaniky $v$ Ukraini. Za red. S.M. Nikolaienka. - K.: Ahrarna nauka, 2015. - 264 p.

9. Vernadskyi V.Y. Trudb po ystoryy nauky. M.: Nauka, 2002. - p. 193.

10. Aniskevych L.V., Voitiuk D.H., Vyhera S.M., Adamchuk N.I., Zakharin F.M., Ponomarenko S.O., Kliuchevych M.M. Pretsyziini fitotekhnolohii v ahropromyslovomu kompleksi Ukrainy: Monohrafiia. K.: NUBiP Ukrainy, 2019. - 798 p.

11. Voitiuk D.H., Chovniuk Yu.V., Humeniuk Yu.O., Sivak I.M., Hutsol O.P. Mekhanizmy vzaiemodii kraivysokochastotnoho vyprominiuvannia z biolohichnymy ob'iektamy ta yikh modeliuvannia: Monohrafiia. K.: NUBiP Ukrainy, 2017. - 626 p.

12. Mekhaniko-ekhnolohichni vlastyvosti silskohospodarskykh materialiv: Pidruchnyk / za red. Yatsuna S.S. - K.: Meta, 2003. - t 448 p.

13. Silskohospodarski ta melioratyvni mashyny: Pidruchnyk / za red. Voitiuka D.H. - K.: Vyshcha osvita, 2004. - $544 \mathrm{p}$.

14. Silskohospodarski mashyny: Pidruchnyk / za red. Voitiuka D.H. - K.: Karavela, 2004. - 552 p.

15. Silskohospodarski mashyny. Osnovy teorii ta rozrakhunku: Pidruchnyk / za red. Voitiuka D.H. K.: Vyshcha osvita, 2005. - 464 p.

16. Mekhanizatsiia, elektryfikatsiia ta avtomatyzatsiia silskohospodarskoho vyrobnytstva: Pidruchnyk u 2 tomakh / za red. Rudia A.V. - K.: Ahroosvita, 2012, T. I - $584 \mathrm{~s}$, T. II - $432 \mathrm{p}$.

17. Silskohospodarski mashyny: Pidruchnyk / za red. Voitiuka D.H. - K.: Ahroosvita, 2015. -679 p.

18. Silskohospodarski mashyny. Osnovy teorii ta rozrakhunku: Pidruchnyk. / za red. Voitiuka D.H., 2-e vydannia, pererob. ta dop. - K.: NUBiP Ukrainy, 2018. - 736 p.

19. Systema tochnoho zemlerobstva: Pidruchnyk / za red. Aniskevycha L.V. - K.: NUBiP Ukrainy, 2018. - $566 \mathrm{p}$.

20. Silskohospodarski mashyny. Osnovy teorii ta rozrakhunku: Navchalnyi posibnyk / za red. Voitiuka D.H. - Sumy: VTD «Universytetska knyha», 2008. $-543 \mathrm{p}$.

21. Teoriia silskohospodarskykh mashyn. Praktykum: Navch. posibnyk / Za red. Yatsuna S.S. Sumy: VTD «Universytetska knyha», 2008. - 201 p.

22. Informatsiini systemy i tekhnolohii: Navchalnyi posibnyk. - Nizhyn: Vydavets PP Lysenko M.M., 2014. - 616 p.

23. Voitiuk D.H., Aniskevych L.V., Volianskyi M.S., Martyshko V.M., Humeniuk Yu.O. Silskohospodarski mashyny. Navchalnyi posibnyk. - K.: Ahroosvita, 2017. - 180 p.

24. Mashyny dlia roslynnytstva. Praktykum. Nizhyn: Vydavets PP Lysenko M.M., 2017. - 352 p. 
Аннотация

\section{Развитие научных идей академика П.М. Василенка в деятельности кафедры, носящей его имя}

\section{Д.Г. Войтюк, Л.В. Анискевич, Ю.О. Гуменюк, И.Н. Сивак}

Статья посвящается 120-летию со дня рождения Петра Мефодиевича Василенко выдающегося ученого в области агроинженерной науки, корифея земледельческой механики, академика ВАСХНИЛ, академик УААН, академика РАСХН, члена-корреспондента НАНУ, доктора технических наук, профессора, лауреата высшей награды в области механизации и электрификации сельского хозяйства - Золотой медали имени академика В.П. Горячкина. Данное исследование освещает вклад академика П.М. Василенко в формирование и развитие научной дисциплины «Земледельческая механика», как технической науки, которая развивается в тесной связи с потребностями сельскохозяйственного производства и изучает механику сельскохозяйственных сред и материалов, технологических процессов и операций, машин и механизмов, машинных агрегатов, поточных линий и систем машин, динамику системы человек-машина в сельском хозяйстве, а также технологические процессы, основанные на использовании немеханических (тепловых, электрических и других) видов энергии, и разрабатывает методы инженерного расчета и проектирования для механизации и автоматизации сельского хозяйства. Около 70 лет плодотворной научно-педагогической деятельности академика П.М. Василенко связано с кафредрой сельскохозяйственных машин. Рассмотрены основные направления деятельности научной школы академика П.М. Василенко и современные направления развития новых технологических систем и техники, над реализацией которых успешно работают ученые кафедры, которая носит имя академика П.М. Василенко. В статье также приведены основные результаты научно-технической и инновационной деятельности, кафедры сельскохозяйственных машин и системотехники им. акад. П.М. Василенко за последние годы ее функционирования.

Ключевые слова: наука; техника; исследования; инновации; кафедра.

Abstract

\section{Development of scientific ideas of academician P.M. Vasylenko in the activities of the department named after him}

\section{D.G. Voitiuk, L.V. Aniskevych, Yu.O. Humeniuk, I.M. Sivak}

The paper is devoted to the 120th anniversary of the birth of Petro Mefodiyovych Vasylenko, an outstanding scientist in the field of Agroengineering Science, a leader of Agricultural Mechanics, Academician of VASHNIL, Academician of NAASU, Academician of RAAS, Corresponding Member of NANU, Doctor of Technical Sciences, Professor, a laureate of the highest award in the field of Mechanization and Electrification - the Gold Medal named after Academician V.P. Goriachkin. This study highlights the contribution of Academician P.M. Vasylenko to the formation and development of the scientific discipline "Agricultural Mechanics", as a technical science which develops in close connection with the needs of agricultural production and studies the mechanics of agricultural environments and materials, technological processes and operations, machines and mechanisms, machine units, flow lines and machine systems, dynamics of the human-machine system in agriculture, as well as technological processes based on the use of non-mechanical (thermal, electrical and other) types of energy and develops methods of engineering calculation and design for mechanization and automation in agriculture. About 70 years of prolific scientific and pedagogical activity of Academician P.M. Vasylenko related to the department of Agricultural Machinery. The main directions of activity of Scientific School of Academician P.M. Vasylenko and modern directions of development of new technological systems and machinery on the implementation of which scientists of the department successfully work, which are named after Academician P.M. Vasylenko. The paper also contains the main results of scientific, technical and innovative activities of the department of Agricultural Machinery and Systems Engineering named after P.M. Vasylenko in recent years of its work.

Keywords: Science; technology; research; innovation; department.

Бібліографічне посилання/ Bibliography citation: Harvard

Voitiuk, D. H. et al. (2020) 'Development of scientific ideas of academician P.M. Vasylenko in the activities of the department named after him', Engineering of nature management, (3(17)), pp. 58 - 64.

Подано до редакції / Received: 12.09.2020

() Д.Г. Войтюк, Л.В. Аніскевич, Ю.О. Гуменюк, І.М. Сівак, 2020

() D.G. Voitiuk, L.V. Aniskevych, Yu.O. Humeniuk, I.M. Sivak, 2020 